KYIV-MOHYLA

HUMANITIES JOURNAL

KYIV-MOHYLA SCHOLARLY PEER-REVIEWED JOURNALS

The Poetry of Bohdan-Ihor Antonych and

Zuzanna Ginczanka in the Context of European Modernism

Author(s): Khrystyna Semeryn

Source: Kyiv-Mohyla Humanities Journal 6 (2019):177-19o

Published by: National University of Kyiv-Mohyla Academy

http://kmhj.ukma.edu.ua/ 


\title{
The Poetry of Bohdan-Ihor Antonych and Zuzanna Ginczanka in the Context of European Modernism
}

\author{
Khrystyna Semeryn \\ National University of Ostroh Academy, Department of Ukrainian Philology
}

\begin{abstract}
This article compares the poetry of two prominent modern writers: Polish-Jewish poetess Zuzanna Ginczanka (Sara Ginzburg, 1917-1945), and Ukrainian Lemko poet Bohdan-Ihor Antonych (1909-1937). They are believed (by Yaroslav Polishchuk et al.) to have certain poetic, stylistic, thematic, and literary similarities. The main discourses of their poetic imaginum mundi are studied with the use of a simple formula that includes five components. Tracing the interplay of nature, childhood, religion, and civilization in the development of an image of a holistic personality in their poetry, I analyze their common and differing ideas, images, motifs, and themes. The article also outlines the underlying similarities of both poets, i. e., their otherness, and their references to childhood as a certain place in their poetry.
\end{abstract}

Key Words: Modernism, otherness, Shoa, Lemko culture, Bohdan-Ihor Antonych, Zuzanna Ginczanka.

\section{(7)}

\section{Introduction}

European literary Modernism is a complex art phenomenon describing much of Ukrainian and Polish literature of the period between the end of the 19th and the first third of the 2oth centuries. However, its chronological and aesthetic boundaries are rather vague. Two prominent figures of modernist national literatures of the first half of the 2oth century are Bohdan-Ihor Antonych (1909-1937), an outstanding Ukrainian Lemko poet, and Zuzanna Ginczanka (Sara Ginzburg, 1917-1945), a brilliant PolishJewish poet. Ukrainian scholars Yurii Andrukhovych, Oleksandr Kyrylchuk, Mariana Barabash, ${ }^{1}$ and others have researched the modernist features of Antonych's poetry.

Yurii Andrukhovych, "Bohdan-Ihor Antonych i literaturno-estetychni kontseptsii modernizmu

[Bohdan-Ihor Antonych and Literary and Aesthetic Conceptions of Modernism]" (PhD

diss., Vasyl Stefanyk Precarpathian National University, Ivano-Frankivsk, 1996); Oleksandr

Kyrylchuk, "Retseptyvni modeli tvorchosti Bohdana-Ihoria Antonycha [Receptive Models of

Bohdan-Ihor Antonych's Creativity]" (PhD diss., Karazin Kharkiv National University, 2007);

Mariana Barabash, "Synerhetychna kontseptsiia tvorchosti u poetiv pershykh desiatyrich XX st.

(B.-I. Antonych, V. Svidzynskyi, I. Annenskyi) [Synergetic Concept of Poetry of the First Decades of the 2oth Century (B.-I. Antonych, V. Svidzynskyi, I. Annenskyi)]," Paradyhma 6 (2011): 111-2O. 
Yurii Klen, however, a Ukrainian modernist writer of the first half of the 2oth century and the author of Visnyk (The Herald), an influential 1920s Ukrainian nationalist journal, evaluated the modernism of Antonych negatively. In addition, contemporary scholar Mykola Ilnytskyi argues against confining Antonych's poetry to Modernism only.2 The influence of Skamander (a group of Polish experimental poets gravitating towards modernist aesthetics, 1918-1939) on the poetry of Zuzanna Ginczanka is apparent. As Yaroslav Polishchuk assumes, there is a similarity between the poetry of Ginczanka and Antonych. ${ }^{3}$ There are some biographical and, more importantly, literary and artistic parallels that prove this assumption, along with a wide range of dissimilarities between them that confound the assumption.

An associate of Julian Tuwim (1894-1953), the most prominent Polish poet of the 1920 and 193os, Zuzanna Ginczanka, was born in Kyiv and grew up in Rivne (then Równe), Ukraine. Her only poetry collection, "O kentavrach" (On Centaurs, ${ }^{4} 1936$ ), is a great achievement of Polish culture. Prominent Ukrainian Lemko poet, Bohdan-Ihor Antonych was born in Novytsia (Ukrainian ethnic territory, today modern-day Poland). He lived a short life of 27 years (exactly as Ginczanka did), published four poetry collections in his lifetime, and two more were published posthumously. Antonych and Ginczanka were marginalized by their societies because of gender, nationality, and culture - their Otherness. They grew up in rural areas and subsequently lived in Lviv. Ginczanka and Antonych have poetic parallels manifested in the motifs, images, and themes of their lyrics. Foremost, these include a common life-affirming pathos, a concept of the world's "great harmony," and a great love for nature.

\section{Theoretical Framework}

The poetry of Bohdan-Ihor Antonych and Zuzanna Ginczanka is highly regarded by critics and literary scholars. Józef Łobodowski, Julian Tuwim, Krzysztof Wilman, Izolda Kets (author of the first monograph on Ginczanka, Zuzanna Ginczanka: życie i twórczość, 1994), Agata Arashkievych (Wypowiadam wam moje życie: melancholia Zuzanny Ginczanki, 2001), Karolina Koprovska, Dorota Wojda ("Sprawy korzenne." Fenomenologia Zuzanny Ginczanki, 2017), Yaroslav Polishchuk, Natalia Belchenko and others have promoted and studied Zuzanna Ginczanka's works. In the preface to a Ukrainian bilingual edition, Poeziia i dolia Zuzanny Ginczanky (The Poetry and Fate of Zuzanna Ginczanka, 2017), Yaroslav Polishchuk pays direct attention to an artistic similarity between the poetry of Zuzanna Ginczanka and Bohdan-Ihor Antonych. ${ }^{5}$ Yevhen Malaniuk is believed to be the first researcher of "Antonych's phenomenon." Subsequently, Sviatoslav Hordynskyi, Danylo Ilnytskyi, Mykola Ilnytskyi, Marko

2 Mykola Ilnytskyi, Vid "Molodoi Muzy" do "Prazkoi shkoly" [From "Moloda Muza" to "Prazka Shkola”] (Lviv: Instytut ukrainoznavstva im. I. Krypiakevych NAN Ukrainy, 1995). 
Pavlyshyn, Yurii Andrukhovych, Ihor Kalynets, Maryna Novykova, Olena Hutyk, Mykola Tkachuk, and others have studied the poetry of Bohdan-Ihor Antonych. Contemporary poet Dmytro Pavlychko was the first to notice a literary connection between Antonych's Zelena Yevanheliia (The Green Gospel, 1938) and Pavlo Tychyna's Soniachni klarnety (Sunny Clarinets, 1918). ${ }^{6}$

\section{A Formula}

To consider the artistic similarities and divergences of the poetry, I use the term imago mundi, the phenomenon describing an individual view of the world and ways of structuring it. For the purposes of this article, the writers' imaginum mundi may be represented with the scheme: nature — childhood — the human — religion (both pagan and Christian) - civilization. I suggest this as the basic formula for examining the poetry's central and integral part - "the human." Poetic exploration of human nature and holistic personality is in many respects based on life experience, especially that obtained in childhood. Furthermore, complex person-nature relations include spiritual experience and guides, which at early stages are incorporated in beliefs and religions, and at subsequent stages comprise the following phenomena: civilization as a way of interaction with the world, the results of human cognition, reflection of the world, and nature transformed by humans. In the poetry of Antonych and Ginczanka, these serve as aesthetic and philosophical keys to the poets' outlooks.

\section{Nature}

Nature influenced the poetry of both authors greatly. The early poetry of Bohdan-Ihor Antonych, "the poet of a spring hangover," 7 is filled with delightful pagan and folkloric pictures of nature. Oksana Dubrova emphasizes the great role nature has for the writer. ${ }^{8}$ The ideas of pristine nature as an ideal place and pattern for human life, and the "great harmony" between a person and the world as an obligatory prerequisite of life are at the core of Zelena Yevanheliia. Subsequently, its cosmogonic and theosophical motifs evolve into the poet's assertion of immortality, the green riot and the festival of plant abundance. The late Antonych appears as a bard of the Universe and of Biological Life. According to him, nature is intertwined with divine and human beings in an indivisible poetic universe. A multitude of floristic and zoomorphic images and tropes, in particular complex metaphors and mystical, esoteric and pagan views of nature as a spiritualized primordial Unity of all things entirely predominate in Antonych's poetry. Mariia Zubrytska states:

6 Dmytro Pavlychko, Persten zhyttia: literaturnyi portret Bohdana-Ihoria Antonycha [The Ring of Life. A Literary Portrait of Bohdan-Ihor Antonych] (Kyiv: Veselka, 2003), 36.

7 Dmytro Pavlychko, Persten zhyttia, 36.

8 Oksana Dubrova, Tvorchi paraleli: Volt Vitmen ta Bohdan-Ihor Antonych [Creative Parallels: Walt Whitman and Bohdan-Ihor Antonych] (Donetsk: LANDON-XXI, 2O12). 
The metaphysical poetry of Antonych is deeply related to folklore and tradition, and firmly rooted in the human archetypal idea of the greatness of nature and its magical properties. These may metaphorically describe the literary works of both poets as the poetics of a dazzling glow of the pagan worship of nature's forces. ${ }^{9}$

Similarly, Zuzanna Ginczanka follows the hedonistic glorification of the sensual beauty of nature in her early poems, such as "Uczta wakacyjna" (1931). The cosmogonic motifs of her later poetry correlate with the texts of Bohdan-Ihor Antonych. They include the glorification of the universal harmony of existence, the "mature wisdom," a permanent search for life's equilibrium. Ginczanka's poetic flora also looks "aristocratic" to a certain extent. There is a vast range of flowers in the author's collection: rhododendrons, daisies, violets, hazels, lilies, among others.

Additionally, cross-cultural similarities in the portrayal of nature by both authors are grounded in mythology. The impact of pagan myths on Antonych is crucial. The writer models his poetic world using solar symbols, water and fire archetypes, items of everyday use, and images of local plants and animals. Ginczanka presents chimeras as the most important zoomorphic image of her poetry. Especially, the Centaur constitutes the philosophical framework for her only poetry collection published in her lifetime. The Firebird appears repeatedly as a complex symbol of the "great harmony."

\section{Childhood}

Childhood constitutes a symbolic chronological bridge between nature and civilization in the development of holistic personality. That period of the lives of both authors was full of a sense of God's presence, though later Ginczanka did not identify herself as a religious person. Both Ginczanka and Antonych poeticized their childhood, which was inevitably connected with natural environments. In Freudianism, infancy is considered as a major period of personality formation and development, in belief that the biographical and psychological roots of human creativity originate from one's early childhood. The purpose of this subsection is to provide a general analysis of childhood projections and various reflections of early years in the poetry of Antonych and Ginczanka.

Danylo Ilnytskyi states, that "The main framework, which became more evident, elaborated and expanded on later, as the greatest concentration of the foregoing and the primordial, is Antonych's childhood." ${ }^{10}$ Referring to the research scheme "topos $\rightarrow$

9 Mariia Zubrytska, “Poetyka ‘zelenoho' chaso-prostoru v tvorchosti B.-I. Antonycha ta B. Lesmiana: sproba porivnialnoho analizu [The Poetics of the 'Green' Chronotope in the Works of B.-I. Antonych and B. Leśmian: An Attempt at a Comparative Analysis]," Paradyhma 4 (2009): 81 .

10 Danylo Ilnytskyi, "Kulturna kartohrafiia zhyttievoho svitu Bohdana-Ihoria Antonycha: Sianotska himnaziia [TheCultural Cartography of Bohdan-Ihor Antonych's World: The Sianok Gymnasium]," Paradyhma 7 (2013): 289. 
tropos $\rightarrow$ anthropos," emphasis is convincingly placed on how the peculiarities of Antonych's imago mundi have been influenced by Lemkivshchyna, his birthplace, which is symbolically presented by the buzzing of greenery and natural magnificence, Lemko songs, folklore, mythology, and a predominantly Christian creed. Danylo Ilnytskyi believes that Lemkivshchyna has become a part of the poet's creative mind.

Pryvitannia zhyttia (Greeting Life, 1931) is the first poetry collection the title of which contains an entire formula for the creative thinking of the young Antonych, and where the credo "eternal youth" is postulated ("Pisnia pro vichnu molodist" (A Song About Eternal Youth, 1931). The poet is a "naked child of the bios," as Alla Bondarenko maintains:

There is a mask of an "archetypal child": the lyrical subject of Antonych's works is "smaller than small" (K. G. Jung). Remarkably, the poet's vision of himself is represented as the individualism of a child (ditvak in Lemko dialect): "I am an always drunken little boy [ditvak] with the sun in my pocket"; "an excited little child captivated by beauty." The "childishness" of the poetic vision of Antonych generates wordplays, masks, which are features of modernist thinking... The author's poetic discourse is constituted of word fragments disguising internal experiences, which is conditioned by the "childishness" of his soul, a feature tabooed by the ethics of maturity.11

Antonych idealizes peasant life ("a distant Lemko village"12; "Kopannia kartopel" (Digging Potatoes), "Koda” (The Code), "Soniashnyk" (The Sunflower), "Baklazhany" (Eggplants), "Ozheredy" (Ricks), among others) and the nature of Lemkivshchyna. He represents the poetics of childhood utilizing the following techniques:

1. a naive sacralization of Lemko loci and local nature ("God was born in a sleigh / in the Lemko town of Duklia"13; "There are grayish grasses on the hills / and a wine-colored stone in the river"14);

2. heathen mythopoetics: pagan concepts (the Sun, "ancient Lada," divination), archetypes (Water, Forest), original metaphors ("the Moon was a groomsman," "Cows are praying to the Sun"15), etc.;

$11 \quad$ Alla Bondarenko, "Slovesni masky 'dytyny buttia' v khudozhnomu movomyslenni B.-I. Antonycha [Verbal Masks of the 'Child of Being' in B.-I. Antonych's Artistic Speech-Thinking]," Slovo i chas 12 (2001): 44.

Bohdan-Ihor Antonych, Try persteni: poemy i liryka [Three Rings: Poems and Lyrics] (Lviv:

Nakladom Bohdana Dorotskoho, drukarnia Naukovoho tovarystva im. Shevchenka u Lvovi, 1934), 11.

13 Bohdan-Ihor Antonych, Zibrani tvory [Collected Works] (New York; Vinnipeg: Slovo, 1967), 86.

14 Antonych, Try persteni, 7.

15 Antonych, Try persteni, 45 . 
3. picturesque scenes of the arduous everyday life of the Lemkos ("There is a winged violin on the wall, / a red pitcher, and a flowered chest ... herbs, wax, seeds..."16 "eternal Lemko indigence" 17 );

4. childhood experience, mnemonic motifs related to childhood (e. g. "Landscapes of memories");

5. the intermedial aspect is represented with incredible images of "singing doors," "musical trees," "the ringing threshold," "the elegiac ring," "the potter of stanzas," "the lyrical apple-tree," etc. Bohdan-Ihor Antonych nostalgically remembers his childhood as a certain place of different colors, sounds, smells, materials, and textures. "Singing doors, a gray sycamore, an old painted threshold. / Places of my childhood days remained like this in my imagination." 18

Zuzanna Ginczanka formulates her own recipe of "simple happiness" in a similar way through childhood visions. "To fall asleep simply like under a small child's blanket in the evening"19 ("Przepis na prostotę życia," 1933). She also has a certain place associated with happy childhood impressions and feelings. Notably, she spent her childhood predominantly in multinational Yiddish-speaking Rivne. She grew up without her parents and was surrounded by many things in her grandmother's house with a ground floor shop. These conditions largely influenced her poetry, especially through inspiring "thing motifs" ("Wiersz o radosnem czekaniu," 1933; "Non omnis moriar," 1942), and an overall melancholia. An everyday domestic idyll had become a measure of her personal happiness. ${ }^{20}$ For this reason, detailed descriptions of a room (e. g. a table, a window, a bed or a wardrobe, someone's belongings) often appear in the poems. Diminutives are additional markers of an idyllic world based on childhood experience ("I am going to clean up my small little room - tidy, white, pretty" ${ }^{21}$ ).

A significant motif of Ginczanka's early poetry is the "naive wisdom" that echoes the idea of a "naive adoration of the world," ${ }^{22}$ which is pivotal for Antonych and which testifies to the inextricable connection of both authors with their childhood. "My wisdom is gadding around the world as a curious inattentive child"23 (cf. Antonych, "I am an always drunken little boy with the sun in my pocket" ${ }^{24}$ ).

There are some metaphors based on associations with material objects: e. g. "Upon the gray platter of land, the green grass is painted," 25 as well as in "Uczta wakacyjna" (1931), and in "Mądrość najmądrzejsza" (1933). However, in "Non omnis moriar" (published

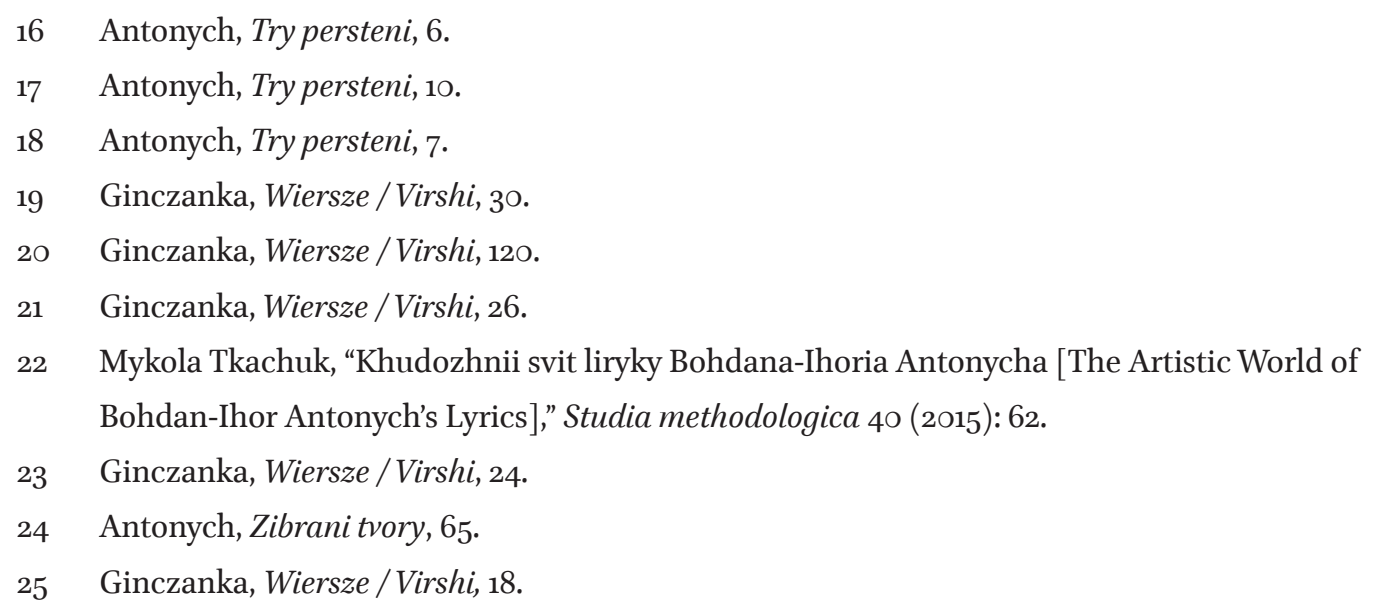


in 1946), an ironic testament highly appreciated by critics, the so-called "thing motif" functions as a bitter irony. There is a monotonous array of different domestic items mentioned in the tragedy of Shoah.

Non omnis moriar - my proud hair,

The meadows of my tablecloths, the hardness of adamantine wardrobes,

The spreading sheets, the precious bedclothes,

And dresses, the bright dresses would remain after me. ${ }^{26}$

Consequently, Antonych's and Ginczanka's poetic and ontological "roots" can be found in their childhood. All aspects of Antonych's image of childhood in his poetry were influenced by his Christian and patriotic upbringing, Lemko cultural environment, his ambiguous "intermedial" thinking (combining primarily music, painting, and literature), and the magnificence of a green nature. The poet's vision and comprehension of the world is based entirely on several convictions:1) all things in the world, animate and inanimate alike, are connected ("I am not a human, I am a plant, and sometimes I am a little fox"); 2) life circulates continuously, and thus everything in the world can reincarnate.

Ginczanka portrays childhood through the contemplation of natural riches (herbs, flowers, and fruits), food, and domestic things. Her poetry focuses mainly on the author's feelings of domestic comfort, and the notion of the "simple joy" of life, despite the melancholy of her texts. According to her view of the Universe, everything is immortal, but in contrast to Antonych, this immortality is partial. Ginczanka's notion of immortality captures the world of things, as it is pictured in "Non omnis moriar." In her poetry she believes in the human ability to leave material things behind.

\section{Religion}

Personal religious experience was highly significant for both writers. The comprehension of the Divine being, God, played an important role in their poetry. Bohdan-Ihor Antonych repeatedly refers to the Christian God in his religious poetry collection, Velyka harmoniia (The Great Harmony, 1932-1933). This early book is deliberately adapted from the structure of the Catholic Mass. Each poem is titled in Latin and represents a Christian spiritual and religious theme along with a certain manifestation of cosmogonic theosophy: "Oh God, let me be like a rock in the stand against the hordes, so that my death will be harmony's last chord" 27 ("De morte, IV"). In Antonych's later poetry the central formula for his poetic view is a fusion of paganism and Christianity. Roman Lubkivskyi notes that "Antonych's God is abstract and at the same time concrete." ${ }^{28}$ The specification of such a God, particularly in the tradition of Lemko

\footnotetext{
26 Ginczanka, Wiersze / Virshi, 91.

27 Antonych, Zibrani tvory, 177.

28 Roman Lubkivskyi, “Antonych i Tychyna: neochevydni tochky dotyku [Antonych and Tychyna:

Hidden Points of Contact]," Den, November 7, 2009, 202, 7, https:/day.kyiv.ua/uk/article/
} 
culture, is a reason for the appearance of picturesque poems like "Rizdvo" (Christmas). In contrast, an abstract Divine being guides Antonych's poetry in an overall sense. Its sacral ritual mythopoetics are embodied in the principle that "biological laws are equal for everyone," as well as in complex pagan-Christian thinking in general.

Unlike Antonych, Ginczanka gravitates to philosophical debate and the comprehension of religious experience. In addition to rare references to a single God, the poetess adapts and interprets biblical stories and motifs in an ironic way. She presents her own version of the creation of the world in "Process," supported by a biblical allusion ("In the beginning there was the heaven and the earth" 29 ). In the last stanza, a topical reference to police surveillance appears which connects this ontological reflection to historical reality. The biblical story of the creation of Adam and Eve forms the basis of the brilliant poem "Poznanie," which focuses on the understanding of gender issues through a patriarchal theme.

\section{Holistic Personality}

Exploring holistic personality within various frameworks, such as poetry, is the main concern of our study. In this regard, Antonych bridges the boundaries of rather opposite realms (e.g. Christian religion and pantheistic nature) by zoomorphic and floristic maps of the world, in contradistinction to a common poetic anthropomorphization of the world: "Antonych was a May bug" 30; "A boy grows up like a raspberry bush" 31; "We will grow in the ground, like pine trees," 32 etc. The peculiar "seasonality" of Antonych's poetry indicates the amalgamation of humans and environment. I mean primarily the poet's self-determinations, like "the poet of a spring hangover," 33 and the attention he pays to the natural seasons, especially spring. He focuses on the world's origins and its initial unity. "Your great primordiality comes in sight like a fern; you are not a plant, you are still a stone; a snake wraps itself around you." ${ }^{44}$ Antonych presents an intricate artistic philosophy. Its central thesis is a complex concept of "three rings." It symbolizes the undeniable integrity of the biological and intellectual potential of a human being, and a never-ending human search for "the great harmony."

In her early period, Ginczanka's "naive wisdom" is prematurely transformed into a mature wisdom. Unlike Antonych, she affirms the "combination of an expressive feminine passion with a cold mind and the world's rationality" 35 through the persuasive image of a centaur, as Yaroslav Polishchuk states. "I declare the passion and the wisdom, /

istoriya-i-ya/antonich-i-tichina-neochevidni-tochki-dotiku.

Ginczanka, Wiersze / Virshi, 48.

Antonych, Zibrani tvory, 155.

Antonych, Zibrani tvory, 8 o.

Antonych, Try persteni, 51.

Antonych, Zibrani tvory, 67.

Antonych, Try persteni, $5^{2}$.

Ginczanka, Wiersze / Virshi, 9. 
which are closely inosculate in the waist, / as a centaur." ${ }^{36}$ Here and thereafter Ginczanka intended to create her personal view of gender entirely through the means of poetry.

Ultimately, that is the main difference between Ginczanka's and Antonych's poetic imaginum mundi. Antonych creates the masculine image of a biological, logocentric world, while Ginczanka breaks the mold of a feminine sensual interpretation of the world in her poetry. Her self-determination within nature is not zoomorphic. It resolutely defines boundaries of the female entity and indicates Ginczanka's acute selfassertion as a woman. Issues of identity are noteworthy as they plagued both artists, albeit to varying degrees. The numerous difficulties in their lives were conditioned by their otherness. Antonych was the Other in Polish Lviv, due to his Lemko Ukrainian roots, language, and culture. Discrimination of Ukrainians by Polish authorities was commonplace at that time. Ginczanka was the Other due to her female gender and Jewish nationality in similar circumstances. Polish female scholars clearly emphasize the "double" discrimination against Ginczanka. They pay particular attention to her status as a "pretty Jewish woman," whose beauty was perceived to be only either demonic or deathly. ${ }^{37}$ In Wypowiadam wam moje życie:melancholia Zuzanny Ginczanki, Agata Araszkiewicz states: "In the Polish canon, she [Ginczanka] is like a double alien, both as a woman and as a Jew. Her biography, as well as her experience, is not clear. ...A woman's writing, surrounded by the atmosphere of oneness or a scandal, is a silent voice, disregarded and erased." ${ }^{38}$ In “Tuwim w spódnicy'? Poetyka Skamandra w twórczości Zuzanny Ginczanki," Karolina Koprowska adds that the poetess aspired to "define herself as a woman." ${ }^{39}$ The stereotypical definition of Ginczanka as "Tuwim in a Skirt" is not random. This nickname deprived her of the status of a poetess, so that she could only make her name as a talented male poet. This assertion is concordant with the famous Ivan Franko description of Lesia Ukrainka as "the only real man" of Ukrainian literature, which still remains an insurmountable barrier for Ukrainian feminist critics.

Ginczanka's feminist self-identification and self-affirmation resonate in "Wyjaśnienie na marginesie":
Nie powstałam
z prochu,
nie obrócę się
w proch. ${ }^{40}$

\footnotetext{
36 Ginczanka, Wiersze / Virshi, $5^{2}$.

37 Mikołaj Gliński, "Sana, Sanechka, Gina: krasa i tavro Zuzanny Ginczanky [Sana, Sanechka, Gina: The Beauty and the Stigma of Zuzanna Ginczanka]." Accessed September 27, 2018, https://culture.pl/ru/article/sana-sanechka-gina-krasa-i-tavro-zuzanni-ginchanki. Agata Araszkiewicz, Wypowiadam wam moje życie: Melancholia Zuzanny Ginczanki (Warsaw: Fundacja OŚKa, 2OO1), 19-20.

Karolina Koprowska, “Tuwim w spódnicy’? Poetyka Skamandra w twórczości Zuzanny Ginczanki," Zeszyty Naukowe Towarzystwa Doktorantów UJ Nauki Humanistyczne 5 (2014): 82. 
The affirmation of her female essence is a denial of the Biblical script of male human creation (the passage is about God saying to Adam, "For you were made from dust, and to dust you will return"). According to it, woman was created second and was made from the man's rib as an assistant to him. In this poem, the author manifests her not feminine but universal human separateness, her own completed and self-perfected being ("Jestem sama niebem" — "I am the heaven myself").

Antonych did not problematize his gender status. In contrast, he declared his Ukrainian identity. The poet formulates energetic and extremely strong aesthetic and national codes in the famous line, "Antonych was a May bug and once lived in cherry trees. / In the cherry trees celebrated by Shevchenko." ${ }^{41}$ It appears as a rather strong and brave statement: just a May bug, but one living in Shevchenko's cherry trees. His vision guides us through the national past tinted by the meaningful concept of "Shevchenko's cherry trees." In contrast, the cosmopolitan poetess Ginczanka refers to a human future without focusing on her own national self-identification, instead positing her own female essence.

\section{Civilization (the City)}

At the end of 19th and in the first third of the 2oth centuries, the urban theme became popular in Ukrainian literature, art, and culture. It largely depended on both the human victory over nature and a commitment to civilization. In Rotatsii (Rotations, 1938), Antonych protests against dead urban culture and civilization's invasion of nature, causing a forthcoming end of the world. The vibrant color palette of Zelena Yevanheliia changes into shades of black, grey, and blue, which symbolize devastation and death. The compilers of the Zibrani tvory (1967) cite Antonych's scholarly article on national art: "Art does not reproduce reality, nor transforms it as others may want; it only creates a separate reality." 42

Antonych is the author of brilliant urban poetry collected in Knyha Leva and especially in Rotatsii. He defines the unity of the social and the natural through the metaphor: "Cities are human zoos." In his earlier "Autobiography," the poet wrote about the gap between the rural idyll of his childhood and his youth, which was connected with city life and its "misery and failures":

And as I descended from the mountains to the noisy cities, In misery and failures I have never cursed or blamed my fate, I calmly watched hurricanes of nasty waves.

My songs are a guelder rose bridge over the river of time, I am a pagan in love with life. ${ }^{43}$

\footnotetext{
41 Antonych, Zibrani tvory, 155 .

42 Antonych, Zibrani tvory, 8.

43 Bohdan-Ihor Antonych, Pryvitannia zhyttia: knyzhka poezii [Greeting Life: Poetry Collection] (Lviv: Dazhboh, z drukarni vydavnychoi spilky “Dilo," 1931), 61.
} 
This poem presents a mythological vertical structure: on the top of the vertical, "in the mountains" (= the sacred world), there are the happy years of childhood, and then the later years, when the author "descends" into urban adult life (= the profane world). The motif of such a "descent" appears repeatedly, accompanied by negative images of urban life, compared to "a filthy marketplace." 44

Antonych wrote much about the city, although he was from a rural background. His city is expressive, eloquent, and ambivalent: the poet both blames and celebrates it. The inclination to spatial geometry, the poetization of sports and athletic human bodies, which are the prerogatives of urban life (the cycle "Bronze Muscles" in Pryvitannia zhyttia), are further developed into broad poetic urban panoramas and an explicit exposure of urbanity with all its shortcomings ("Mista i muzy," "Rotatsii," etc.). Note that the ambivalent image of Antonych's city also has apocalyptic rhetoric caused by the unnatural and abnormal essence of the city.

The idea of the city, which is ontologically distant from nature or partly denies it, is an additional characteristic of Zuzanna Ginczanka's poetry. "Ucieczka" (1937) contains a key motif of escaping from civilization to the bosom of nature: "I am falling into the chestnuts' luxury, into the sway of the hazels and willow trees." ${ }^{45}$ Coupled with it, the writer's attachment to the topos of the small town strengthens, as a small town is the light version of urban civilization, which involves maintaining a connection with natural environments and traditions. This thought is evident in the poem "Zamiast różowego listu" (1932). "Moje malutkie miasto" is an imagined construct, a place of the unfulfilled existence of a love affair, which may well be an urban center ("My little town could be bigger than a thousand towns"46) or a hamlet ("My little town could be the smallest one" 47 ).

Apocalyptic visions are a common significant motif for both writers. In "Współczesność" (1937), Ginczanka uses an antithesis of two ships, both of which would end up crashing on a reef, regardless that one is fragile and the other seemingly sturdy. Subsequently, due to the anticipation of a future catastrophe (Shoah) and a premature death, the fear of an unknown future grows greatly. "Will we live or will we die [in the sense of winning or losing]?" — the writer asks rhetorically.48

In "Apokalipsys" (The Apocalypse), Bohdan-Ihor Antonych depicts the end of life, which inevitably circulates back to new life. We suppose his apocalyptic vision is definitely life-affirming. "Where no stone is left upon no stone, where the mountains line up, / is where masons once again are putting up a new prison of flowery slabs." 49

\footnotetext{
44 Antonych, Pryvitannia zhyttia, 26.

45 Ginczanka, Wiersze /Virshi, 64.

46 Ginczanka, Wiersze / Virshi, 20.

47 Ginczanka, Wiersze / Virshi, 20.

48 Ginczanka, Wiersze /Virshi, 82.

49 Bohdan-Ihor Antonych, Knyha Leva [The Lion's Book] (Lviv: Drukarnia Naukovoho tovarystva im. Shevchenka, 1936), 31.
} 
Iryna Herasymiuk notes, "Describing the urban world in Rotations, Antonych foretells its inevitable death. And death will come to the city in the form of the Apocalypse." 50 The author's philosophy of the city appears in "Surmy ostannioho dnia" (Last Day's Trumpets) and "Kinets svitu" (The End of the World). According to it, nature (the new flood) will soon destroy the city as something inanimate, artificial, and chaotic. This means that Antonych transferred the active role of supervisor and executioner from a single God to a diverse pantheistic world in a precisely pagan manner. "And, having raised its blue hands, like a prophet, the moon, started cursing the city. For all its sins and all its faults, corruptness, treachery, and malice." ${ }^{51}$

In contrast, Ginczanka's urban vision has a rather positive interpretation, despite its vague apocalyptic motifs, while Antonych saw the city mainly as something dead and contrary to nature. To a certain extent, it is possible to find a pantheistic solar cult, a coherent pagan metaphor of the world, the sensitive eroticism of nature, as well as the unity of these three elements, together with the superiority and primacy of nature, in his poetry. Ginczanka's poetry developed in a complex way: from the vitalism and adoration of nature in "Uczta wakacyjna" to sensual eroticism and physiological visions ("Fizjologia," on the one hand, and irony and satire, in the anticipation of a violent premature death, on the other hand). "I have inevitable death, circulating in my veins like a needle." ${ }^{52}$

\section{Conclusions}

The issue of the poetic similarities and dissimilarities of Zuzanna Ginczanka and Bohdan-Ihor Antonych remains a complex one in Ukrainian and Polish literary studies. All things considered, it seems reasonable to outline the following important observations. Both writers had a great interest in profound metaphors and "heavy" poetic structures, the condensation of sense and meaning. They delighted in nature and provided their own "solar cult," as well as idealized the sentimental picturesque childhood both spent surrounded by the splendors of nature. Regarding religion, the poets had specific attitudes to a transcendental Divine being. Antonych combined his native Catholic-Lemko tradition and Christian-pagan pantheism. Ginczanka, however, viewed religious dogma and her religious experience ironically. She frequently refers to world mythology in her poems. An important common motif is the question of self-identity. This includes the gender (female) identity of Ginczanka and the national (Ukrainian) identity of Antonych, although these cannot be compared on equal terms. The last meaningful aspect is the urban theme. While Ginczanka develops a constant 
atmosphere of the dread of catastrophe, Antonych shows the continuous movement of life, the power of bios over ethos, and the chaos of the city.

These and other artistic parallels, as well as biographical ones, confirm a certain specificity of literary history constituting strong internal canons of cultural development and cultural and historical patterns that guided the course of poetic thought in Ukraine and the nearby regions of neighboring countries in the first third of the 2oth century. Thus, extra-literary factors had a substantial impact on the poetry of both writers, as well as on the works of all artists in Ukraine at that time.

\section{Bibliography}

Antonych, Bohdan-Ihor. Knyha Leva [The Lion's Book]. Lviv: Drukarnia Naukovoho tovarystva im. Shevchenka, 1936.

Antonych, Bohdan-Ihor. Pryvitannia zhyttia: knyzhka poezii [Greeting Life: Poetry Collection]. Lviv: Dazhboh, z drukarni vydavnychoi spilky “Dilo," 1931.

Antonych, Bohdan-Ihor. Try persteni: poemy i liryka [Three Rings: Poems and Lyrics]. Lviv: Nakladom Bohdana Dorotskoho, drukarnia Naukovoho tovarystva im. Shevchenka u Lvovi, 1934.

Antonych, Bohdan-Ihor. Zibrani tvory [Collected Works]. New York; Vinnipeg: Slovo, 1967.

Araszkiewicz, Agata. Wypowiadam wam moje życie: Melancholia Zuzanny Ginczanki. Warsaw: Fundacja OŚKa, 2001.

Bondarenko, Alla. 'Slovesni masky 'dytyny buttia' v khudozhnomu movomyslenni B.-I. Antonycha [Verbal Masks of the 'Child of Being' in B.-I. Antonych's Artistic Speech-Thinking]." Slovo i chas 12 (2001): 43-49.

Dubrova, Oksana. Tvorchi paraleli: Volt Vitmen ta Bohdan-Ihor Antonych [Creative Parallels: Walt Whitman and Bohdan-Ihor Antonych]. Donetsk: LANDON-XXI, 2012.

Gerasymuk, Iryna. "Antonych: zanadto blyzko do smerti? [Antonych: Too Close to Death?].” Accessed September 30, 2018. http://zhurnal.lib.ru/g/gerasimuk_i_w/ antonychzanadtobluzkodosmerti.shtml.

Ginczanka, Zuzanna. Wiersze /Virshi:polskoiu ta ukrainskoiu movamy [Poetry: In Polish and in Ukrainian]. Lviv: Vydavnytstvo "Forum vydavtsiv," 2017.

Gliński, Mikołaj. "Sana, Sanechka, Gina: krasa i tavro Zuzanny Ginchanky [Sana, Sanechka, Gina: The Beauty and the Stigma of Zuzanna Ginczanka]." Accessed September 27, 2018. https://culture.pl/ru/article/sana-sanechka-gina-krasa-itavro-zuzanni-ginchanki.

Ilnytskyi, Danylo. “Kulturna kartohrafiia zhyttievoho svitu Bohdana-Ihoria Antonycha: Sianotska himnaziia [The Cultural Cartography of Bohdan-Ihor Antonych's World: The Sianok Gymnasium]." Paradyhma 7 (2013): 284-304.

Ilnytskyi, Mykola. Vid "Molodoi Muzy" do "Prazkoi shkoly" [From "Moloda Muza" to "Prazka Shkola"]. Lviv: Instytut ukrainoznavstva im. I. Krypiakevych NAN Ukrainy, 1995 . 
Koprowska, Karolina. “Tuwim w spódnicy'? Poetyka Skamandra w twórczości Zuzanny Ginczanki." Zeszyty Naukowe Towarzystwa Doktorantów UJ Nauki Humanistyczne 5 (2014): 79-88.

Lubkivskyi, Roman. "Antonych i Tychyna: neochevydni tochky dotyku [Antonych and Tychyna: Hidden Points of Contact]." Den, November 7, 2009. https://day.kyiv.ua/ uk/article/istoriya-i-ya/antonich-i-tichina-neochevidni-tochki-dotiku.

Pavlychko, Dmytro V. Persten zhyttia: literaturnyi portret Bohdana-Ihoria Antonycha [The Ring of Life. A Literary Portrait of Bohdan-Ihor Antonych]. Kyiv: Veselka, 2003 .

Tkachuk, Mykola. "Khudozhnii svit liryky Bohdana-Ihoria Antonycha [The Artistic World of Bohdan-Ihor Antonych's Lyrics]." Studia methodologica 40 (2015): 53-70. Zubrytska, Mariia. "Poetyka 'zelenoho' chaso-prostoru v tvorchosti B.-I. Antonycha ta B. Lesmiana: sproba porivnialnoho analizu [The Poetics of the 'Green' Chronotope in the Works of B.-I. Antonych and B. Leśmian: An Attempt at a Comparative Analysis]." Paradyhma 4 (2009): 81-87.

(2)

Khrystyna Semeryn received her MA diploma in philology with honors from the National University of Ostroh Academy in 2018. She was awarded 1st place in several research contests, such as the All-Ukrainian Contest of Student Research Works in 2017. She is an editor of the Geopoetic Studies Literary and Scholarly Almanac. Her research interests include Jewish images in Ukrainian modernist literature, 2oth century European literature, the literary works of Viktor Domontovych, Yurii Kosach, Zuzanna Ginczanka, Vasyl Stus, W. S. Maugham, and Gustav Meyrink. She is working on her dissertation on the Jewish world in Ukrainian short fiction. 